\title{
Impact of Farm and Non-Farm Micro-Enterprise Diversifications on Household Dietary Diversity in Malawi
}

\author{
A. K. Edriss and A. Mehare
}

\begin{abstract}
Micro-enterprising is crucial for improving rural households' food and nutrition status in subsistence agrarian economy like Malawi. There are no studies that have concurrently analyzed the roles of farm and non-farm microenterprise diversity on household dietary diversity (proxy measure of household food access) in Malawi. With the following objectives, the study jointly (1) analyzed the effects of farm and non-farm micro-enterprises diversifications on rural household food access, and (2) analyzed relevant socio-economic and institutional factors on household dietary diversity in selected districts of Malawi.

Data were collected from 1827 households; whereby 779 households were engaged in some kind of farm and non-farm micro-enterprises in six districts with high concentration of micro-businesses and population densities. Both parametric and parametric descriptive statistics, Poisson and Negative Binomial regressions were used for estimations. Of all the factors associated with household dietary diversity, farm and non-farm enterprise diversity, as well as expenditure on food items had played major roles in influencing household dietary diversity. Increasing farm and non-farm micro-enterprise diversity by one micro-business group is associated with the possibility of consuming or having access to all 12 groups of food by the households. Holding other things constant, it is surprisingly found that nutrition education $(34.2 \%, \rho=0.000<0.001)$ influenced household food dietary diversity more than household heads with formal education (average 5 years of schooling); suggesting that nutrition education, if directly delivered to the household heads regardless of their formal education level, is one of the major factors that can positively and significantly affect household dietary diversity in Malawi.

These results also resonate to the Government of Malawi's overarching policy goal of furthering income-generating social and economic activities in order to become less reliant on handouts and donors at large. Besides increasing only starchy staple food or monotonous cereal-based diet through various agricultural subsidy programmes, such micro-enterprising programs are also needed to enhance by targeting energy and nutritious food supply that are essential if the country is aiming to expand its industry and service sector with healthy population.
\end{abstract}

Index Terms - dietary diversity, micro-enterprises, negative binomial, Malawi.

\section{INTRODUCTION}

Achieving Nutrition security is one of the Government of Malawi's top priority agenda. In the third version of the Malawi's Growth and Development Strategy (MGDIII),

Published on June 17, 2020.

A. K. Edriss, Lilongwe University of Agriculture and Natural Resources LUANAR), Malawi.

(corresponding e-mail: abdikhalil@yahoo.com) nutritional security is one of the key priority areas. Over the years, there has been emphasis on increasing maize production to achieve food security as a mechanism through which to achieve nutritional security. Another strategy or agricultural related policy that was pursued for over 20 years included agricultural credit for micro-enterprises through Rural Lending Institutions to improve their livelihoods and thereby achieving nutritional security especial among underfive children.

The literature on agriculture-nutrition linkages has rarely focused on micro-enterprise diversity, and only few studies have analyzed the role of nutrition information on either household nutritional status or household dietary diversity. Furthermore, there are no studies to the best of my knowledge that have jointly analyzed the roles of farm and non-farm micro-enterprises on household dietary diversity, especially in rural Malawi. Studies in Nepal [1], Zimbabwe [2] and Ethiopia [3] were done to show that agriculture has a direct impact on household food security and nutrition through three main pathways, which are commercialization, market access and women empowerment. Other studies such as [4] found little evidence of a positive relationship between commercialization and nutritional status in Malawi, Tanzania, and Uganda. In Ethiopia, [3] reported that enhanced nutrition knowledge improved children's dietary diversity only in areas with relatively good market access.

However, the focus of this research is twofold, which complements and supplements the marketing side of agrobusiness: (1) analyzing the effects of farm and non-farm micro-enterprises diversifications on household dietary diversity or achieving nutrition adequacy at household level, and (2) analyzing relevant socio-economic and institutional factors on household dietary diversifications or proxy to food access in quantity and in selected districts of Malawi.

\section{ANALYTICAL FRAMEWORK}

It is vastly claimed that Micro-Enterprises funded through Rural Lending Institutions are important sources of livelihood for many low-income households in developing countries. Experiences around the world have shown some mixed outcomes. The Grameen Bank in Bangladesh is a well-known example of these innovative micro-finance or credit programs for many micro-level enterprising and business initiations and diversifications. The bank has a proven record in reaching the

A. W. Mehare, Haramaya University, Ethiopia. (e-mail: abule.mehare@gmail.com) 
poorest and simultaneously achieving high repayment rates [5]. Some of the achievements are that income earned by rural household is largely spent in meeting family needs, with likely benefits for child welfare, nutrition, education, and health.

Like many developing countries, Malawi has seen the emerging of several such micro-finance institutions targeting the rural households. Through such innovative micro-finance schemes, it is believed that men and women's entrepreneurships are self-directed poverty reduction strategy, particularly when agriculture or formal employers cannot supply enough work, let alone enough returns. Throughout sub-Saharan Africa, households are traditionally characterized by being interdependent. Within subsistence farming household, some studies [6] and [7] have shown that when a rural household has extra income, the additional income is more likely to translate into high caloric intake and nutrients of the whole family.

In light of promotion of micro-enterprises through small credits in Malawi since 1994, it is believed that rural households are beginning to have some additional earnings from diversifying enterprises in both agro- and non-agrobased (e.g., trade and sales) enterprising. Hence, this study assessed the direct or indirect impact of such non-farm microenterprise diversifications on nutritional status of households in rural Malawi.

\section{A. Farm Micro-Enterprising}

In addition to health sector, it is widely accepted that agriculture and other sectors play a very important role in reducing undernutrition [8], [9] and [10]. Food security is commonly defined as a situation when all people at all times have physical, social, and economic access to sufficient, safe, and nutritious food to meet their dietary needs and food preference for an active and healthy life [11].

Theoretically, market-oriented production should allow farmers to increase their incomes and purchase more nutritious foods [12]. Therefore, it is important to explore the effects of farm micro-enterprising on income and household dietary diversity among the rural population.

\section{B. Non-Farm Micro-Enterprising}

Complementing farm micro-enterprising, another aspect of enterprising that widely agreed to have helped rural household are non-farm micro enterprises such as small-scale trade/sales, bar/restaurant, transport and storage, hair saloon and others. These micro-enterprises could easily be made affordable to start with and would create additional income generating activities among the poor households to supplement their food and dietary requirements.

Since Malawi's development agenda is increasingly focusing on measures to transform the agriculture sector generally, and encouraging private sector development, nonfarm enterprising is important in this respect. It is therefore imperative that the relationships among non-farm enterprising and dietary diversity outcomes are empirically investigated. Following [13] categorization, the following farm and non-farm enterprises were considered in this study - cereals, horticultural, tubers and roots, legumes and pulses, whole sale, retail sales, restaurant and bar, manufacturing, transport and storage, community and social services; noting that for the purpose of this study and based on local economy, microenterprise is a small business that usually operates with fewer than 5 people and is started with a small amount of capital ( $\leq$ US $\$ 150$ on average) specialized in providing goods or services for their local areas for at least 2 years.

\section{Household Dietary Diversifications}

Based on [14] a modified Household Dietary Diversity Score (HDDS) was calculated for each household using recall data on consumption of foods over the previous 24 hours during the survey. The modified HDDS, then, is a count variable from 0 to 12 , as well as believing that shorter recall period improves the accuracy of estimates compared with longer recall periods of 7 days [14] and thus a 24 hour recall period was used in the survey with each food group counting toward the household score if a food item from the group was consumed by anyone in the household in the previous 24 hours. The consumed groups or items were categorized into 12 groups namely, meat (goat, beef and chickens), eggs, fish, fruits, cereals, milk and dairy products, vegetables, fruits, legumes and pulses, tubers and roots, oils and fats, as well as others (beans, pea, etc.).

\section{Methodology}

This section deals with study area, sampling frame, design, sampling method and estimation methods. The study used both primary and secondary data, where necessary.

\section{A. Study Area}

The primary data were purposely collected from six districts, with high concentration of farm and non-farm enterprises and population in Malawi. The districts are Mzimba, Mzuzu, Lilongwe, Kasungu, Mangochi and Zomba districts.

\section{B. Sampling Methods}

The sample frame comprises of two categories, farm, and non-farm micro-businesses in rural areas of the districts Using stratified random sampling, the comprehensive crosssectional study collected data on socio-economic characteristics of the households, current levels of knowledge, attitude, and practice of health in the households, socio-economic, institutional characteristics, and measure levels of different health indices (anthropometry) in the selected households.

\section{Sample Size Determinations}

Data were collected on two stratified groups, those who participated in farm micro-businesses and those who ran nonfarm micro-enterprises. It was intended to compare the two groups or strata. Taking into considerations a number of factors, the sample size for the survey was determined as shown next, and then the optimal sample size for each group was theoretically taken with equal ratios (farm microenterprises to non-farm microenterprises, 50:50) following [15].

However, estimating the optimal total sample size required to determine the proportion of micro-enterprise owners and a district with the highest population among the six districts that had been selected.

1) Anticipating the proportion about to be measured, Malawi Government documents [16] reports that of the total 
population, $30 \%$ runs some kind of enterprise. The normal level of confidence on estimates is set at $\pm 5 \%$.

2) Sample size estimations:

$\mathrm{p}=$ previously known micro-enterprises proportion $=30 \%$ [13].

$\mathrm{e}=\%$ error within $= \pm 5 \%$. For confidence of $95 \%, \mathrm{Z}=1.96$

(2-tailed test)

$\mathrm{n}=1,230,834$ population (taken high population size for Lilongwe to avoid district sample biases).

Therefore, the sample size is:

$n=\frac{z^{2} p q N}{e^{2}(N-1)+z^{2} p q}=\frac{1.96^{2}(0.3)(0.7) 1230834}{0.05^{2}(1230833)+1.96^{2}(0.3)(0.7)}=322.61$

From the six districts, the total sample size for the survey is expected to be $6 \times 323=1938$. However, taking into consideration the size of each district with respect to its population size and using probability proportional sampling (PPS) method, the sample size for each district is summarized in Table I as follows.

TABLE I: PRIMARY DATA SAMPLE SIZES BY DISTRICT

\begin{tabular}{ccc}
\hline Districts & $\begin{array}{c}\text { Number of } \\
\text { Household } \\
\text { Population [13] }\end{array}$ & $\begin{array}{c}\text { PPS }^{+} \text {Estimated Sample } \\
\text { sizes for each district }\end{array}$ \\
\hline Mangochi & 797,061 & 364 \\
Zomba & 579,639 & 275 \\
Lilongwe & $1,230,833$ & 583 \\
Kasungu & 627,467 & 300 \\
Mzimba & 727,931 & 345 \\
Mzuzu city & 133,968 & 71 \\
Total & $4,096,900$ & $\mathrm{n}=1938$ \\
\hline
\end{tabular}

Table I summarizes sample sizes with respect to population size by districts. In order to control district and regional effects that might influence some investment and business opportunities, all the three regions (northern, central and southern) of Malawi were represented in the household survey as Mangochi and Zomba districts are in Southern region, Lilongwe and Kasungu districts are in the Central region, Mzimba and Mzuzu are in the Northern region.

\section{Estimation and Analytical Techniques}

Descriptive statistics following both parametric and nonparametric procedures were performed. Statistical tests such as p-value, t-test, $\chi^{2}$ and others were used, where necessary. Simple interpretations, associations and comparative analysis among indicators were done, as well as, compared with some national statistics.

In order to investigate the relationship between various socio-economic and institutional variables including nutrition education, micro-enterprises diversification, household food dietary diversification, the following regressions models such as Poisson and Negative binomial models were applied:

\section{E. Micro-enterprises (Farm and Non-farm Business) Diversity}

To investigate the effects of various socio-economic and institutional characteristics on farm and non-farm microenterprises, the following model was used:

$\mathrm{HMED}=\alpha_{0}+\mathrm{f}$ (socio-economic variables, institutional variables) $+\varepsilon$
HMED is household micro-enterprises diversifications, which is categorized into 12 different business groups; each micro-enterprise is counting toward the household's score if a business is run from the group by anyone in the household in the last 2 years. The modified HMED, then, is a count variable from 1 to 12 . Both farm and non-farm microenterprises used to calculate the modified HMED included cash crops, grains, horticulture, legumes (plus pulses), tubers (plus roots), whole sale, retail sale, restaurant/bar, manufacturing, transportation/storage, community/social services and others (construction, mining, etc.). The categorization follows Malawi's National Statistical Office recent classification used during Household Integrated Survey 3 (HIS3) and HIS4 surveys in 2013/2016.

\section{F. Household Dietary Diversity}

To determine the relationship between household dietary diversity (HHDD) and micro-production-socio-economic characteristics, a modified Household Dietary Diversity Score was calculated for each household using recall data on consumption of foods over the previous 24 hours during the survey [14]. As suggested previously through various literatures [2], the shorter recall period was used in order to improve the accuracy of estimates compared with longer recall periods of a week or a month. The food items were categorized into 12 different food groups with each food group counting toward the household score if a food item from the group was consumed by anyone in the household in the previous 24 hours. The following Poisson or Negative binomial model was used:

\section{$\mathrm{HHDD}=\beta_{0}+\mathrm{f}($ microenterprise diversity, socio- economic characteristics, institutional variables, household farm diversity) $+\varepsilon$}

The modified HHDD is household dietary diversity score. It is a count variable assigned a number from 1 to 12 , which measures nutritional security at the household level. The food groups used to calculate the modified HHDD includes meat, eggs, fish, fruits, vegetables, cereals and maize, legumes and pulses, cassava, milk and dairy products, tubers oils and fats, and others (such as beans, peas, etc.).

\section{RESUlTS AND DisCUSSIONS}

In this section, various results are reported and discussed in relation to farm and non-farm microenterprises, affecting household dietary diversity in highly microenterprise populated districts of Malawi.

\section{A. Demographic Characteristics}

Of 1938 sample size estimated, 1827 samples were found to be complete and clean (or valid samples) for analysis. Table II reports the sample characteristics. About $72 \%$ of the households are headed by male, while $28 \%$ headed by female. The household size is about 5 persons on average, while the average household head age is about 44 years. According to [13] and [16], the population aged between 15 and 64 years (economic-active population) made up almost $50 \%$ of the population in 2016. Thus, the results here suggesting most household heads are involved in some kind of occupation 
including both in farm and non-farm enterprising. Also, household heads have completed 4.9 years of schooling (or approximately reached Standard 5 level) in the districts.

\begin{tabular}{|c|c|c|}
\hline Household Characteristics & $\begin{array}{c}\text { Proportion } \\
\mathrm{n}=1827\end{array}$ & $\begin{array}{c}\text { Malawi } \\
(\mathrm{NSO}, 2014) \\
\end{array}$ \\
\hline \multicolumn{3}{|l|}{ Sex } \\
\hline Male & 71.84 & 75.1 \\
\hline Female & 28.16 & 24.9 \\
\hline Size & 4.66 & 4.7 \\
\hline Mean children under 5 years & $2.6 \pm 0.72$ & - \\
\hline Age household head (years) & 43.81 & 54.3 \\
\hline \multicolumn{3}{|l|}{ Education } \\
\hline None & 65.39 & 72.4 \\
\hline PSLE & 9.65 & 11.3 \\
\hline JCE & 11.73 & 9.0 \\
\hline MSCE & 9.0 & 5.6 \\
\hline Tertiary & 3.13 & 1.7 \\
\hline Others & 1.1 & - \\
\hline Literacy & 69.6 & 71.3 \\
\hline \multicolumn{3}{|l|}{$\begin{array}{l}\text { Occupation of household } \\
\text { head }\end{array}$} \\
\hline Farming & 79.63 & 81.3 \\
\hline Laborer & 6.66 & - \\
\hline \multicolumn{3}{|l|}{ Micro-enterprising } \\
\hline Domestic & 42.6 & 33.3 \\
\hline \multirow[t]{2}{*}{ Others } & 1.96 & - \\
\hline & 0.39 & - \\
\hline \multicolumn{3}{|l|}{ Marital Status } \\
\hline Married & 74.32 & - \\
\hline Widow & 17.21 & - \\
\hline Divorced & 4.17 & - \\
\hline Others & 4.30 & - \\
\hline
\end{tabular}

It is important to note that education of household head in particular is, arguably, the most important determination of economic situation and health of the household; in terms of education: about $70 \%$ of the household heads are literate. However, very similar education levels were obtained in contrast to [16] report; showing that about $12 \%$ have completed primary school, $9 \%$ secondary school and $1.1 \%$ had reached to some kind tertiary education level.

Table II also reports findings related to occupation of the household head, as well as marital status of the household head believing that such socio-economic characteristics might have effects on both economic and health situations in the household, in general. As in the case in agro-based economies around the world, most (79.6\%) of the household heads are involved in some kind farming occupation. And $11 \%$ of the household heads were involved in some kind of farm and non-farm micro-enterprise business in the districts of Malawi. According to [13] and [16], about $81 \%$ of the households were involved in farming or agricultural occupation; and it is also reported that $21 \%$ had run some type of non-farming business in the country.

\section{B. Household Farm and Non-farm Assets}

Referring to [16] report, durable goods refer to appliances such as radio, mortar, bicycle, chair, bed, table, iron, clock, television, and computer. Production durable goods refer to items used in agricultural production such as hand hoe, watering can, panga knife and ox-cart among others. The distributions of farm and non-farm assets, farm size and land ownership are reported in Table III.

The average farm size is 0.66 hectares with standard deviation of \pm 0.45 , implying that there is high variation of land size owned by the households; households own $69.1 \%$ of the land, which is not significantly different from $71 \%$ for Malawi based on the 2014 report.

TABLE III: PROPORTION OF FARM AND NON-FARM ASSETS OWNED BY HOUSEHOLDS

\begin{tabular}{lcc}
\hline \multicolumn{1}{c}{ Assets } & $\begin{array}{c}\text { Percentage } \\
\mathrm{n}=1827\end{array}$ & $\begin{array}{c}\text { Malawi } \\
{[13]}\end{array}$ \\
\hline Farm assets & 89.8 & 91.0 \\
Hand hoe & - & 9.0 \\
Slasher & 86.7 & 40.0 \\
Panga Knife & 35.9 & 38.4 \\
Axe & 9.0 & 1.0 \\
Ox-cart & 47.8 & - \\
Others & & \\
Non-farm assets & 37.2 & 45.7 \\
Radio & 35.7 & 42.2 \\
Bicycle & 10.1 & 13.0 \\
Tape/CD/DVD & - & 11.6 \\
Television & 29.6 & 19.1 \\
Iron & 61.5 & 45.9 \\
Mobile Phone & 20.1 & 205 \\
Others & 69.1 & 71.1 \\
Own farm & 0.66 & 0.4 \\
Farm size (hectares) & & \\
\hline
\end{tabular}

Of all the farm assets, about $90 \%$ of households' own hand hoe, followed by panga knife and axe, which are the main tool for cultivating or digging and other farming activities among rural households in Malawi. Similarly, among nonfarm assets mobile phones (61.5\%), radio (37.2\%) and bicycle $(35.7 \%)$ are important durable assets among the rural households.

\section{Credit, Loans, Constraints and Utilization of Loans}

According to [13] and [16] reports, credit and loans are important sources of additional finance for households, either to relieve a household during a difficult period or enable it to expand its activities. These are needed as for increase in demand for investment in both agricultural and nonagricultural enterprises.

This study collected primary data on membership of organization, access to credits, amount of loan, sources of loan, as well as constraints households faced when borrowing formal or informal loans. Note that of the total 1827 samples, it was found that 779 households own some kind of microenterprises in the districts. Table IV highlights the distribution of micro-enterprising households who were involved in credits and membership, sources of loan/credit, as well as insights into the challenges they have come across when borrowing.

TABLE IV: DISTRIBUTION OF ACCESS TO CREDIT AND SOURCES OF

\begin{tabular}{lcc}
\multicolumn{3}{c}{ CREDITS/LOANS } \\
\hline \multicolumn{1}{c}{ Characteristics } & $\begin{array}{c}\text { Percentage } \\
\text { Valid n=767 }\end{array}$ & $\begin{array}{c}\text { Malawi } \\
{[13]}\end{array}$ \\
\hline Access to Credit & 33.4 & 36.2 \\
Mean credit or loan (Malawi & $4658.84 \pm 8779.7$ & - \\
Kwacha) & & \\
Sources of loan/credit & 7.8 & 13.2 \\
Relatives & 3.5 & 13.5 \\
Neighbors & 4.4 & 0.9 \\
Local merchant & 8.5 & 7.9 \\
Money lender & 0.9 & 0.8 \\
Employer & & \\
Religious institutions & 1.2 & 1.1 \\
Others & 8.8 & 3.6 \\
\hline
\end{tabular}

Almost equally, most households obtained their loans from relatives $(7.8 \%)$ and money lenders $(8.5 \%)$, while employers 
and religious institutions were the least to provide loans or credits. Looking at the average amount of loan/credit, which is about MK5000 with the maximum amount MK80, 000; the variation of the loan ranges from MK3000 to MK80000 which is reflected with high standard deviation of MK8777.70. This directly or indirectly suggests that for an average borrower it would be difficult to run microenterprises effectively as it may not be sufficient as a start-up capital highly varies.

Furthermore, Table V presents constraints household heads faced when borrowing from various sources. Regardless of the type of micro-enterprises the households have run, with no significant different, the types of constraints they had faced are almost the same.

TABLE V: CONSTRAINTS HOUSEHOLD HEADS FACED WHEN BORROWING THE ARRANGEMENT OF CHANNELS

\begin{tabular}{ccc}
\hline Characteristics & $\begin{array}{c}\text { Percentage } \\
\mathrm{n}=767\end{array}$ & $\begin{array}{c}\text { Malawi } \\
{[13]}\end{array}$ \\
\hline Types of Constraints & & \\
Lack of collaterals & 74.7 & 44.6 \\
Credit default & 3.5 & 12.0 \\
Delays in credit & 12.5 & 19.0 \\
Gender bias & 4.3 & 6.1 \\
Loan diversions & 4.9 & 10.2 \\
Others (illness, etc.) & 10.1 & 8.1 \\
\hline
\end{tabular}

In fact, of the $33.4 \%$ of the households who had access to credit or loans, about $75 \%$ of had no collaterals since that were the major reasons for not able to borrow from the lenders, in general. Furthermore, delays in credit process also blocked most households or made them give up from getting loans/credits. These results reflect what was reported by National Statistical Office in Malawi [13].

The same report shows that some people borrowed for investments while others borrowed for consumption purposes. Business start-up stood out as the major reason for seeking a loan (54\%), followed by purchase agricultural inputs $(19 \%)$ and purchase for non-farm inputs $(11 \%)$ in Malawi. Fig. 1 presents utilization of the loans or reasons for borrowing in the last 2 years prior to the survey.

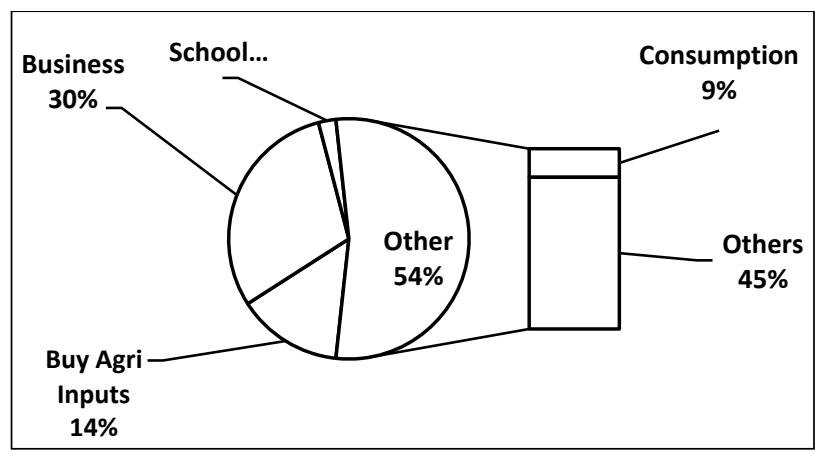

Fig. 1. Purposes for loan or credit.

Fig. 1 indicates that most households borrowed to do some kind of farm or non-farm business (30\%), followed by purchasing of agricultural inputs such as fertilizers and seed. Almost $50 \%$ of the household heads did not want to disclose the reasons for borrowing; perhaps it might be used for treatment of health issues or even paying back other loans, as well as saving for lean periods as was discovered during focus group discussions. Also, Fig. 1 shows that most (30\%) of households obtained loans to run some kind of enterprises in order to supplement or complement in supporting their livelihoods, in general.

\section{Micro-enterprise Types, Income and Expenditures}

Information on the structure and the operational characteristics of household of both agricultural or farm and non-farm enterprises were collected in the survey. This section presents detailed information on types of microenterprises, farm production activities, market for the products, business distribution and financial performance. These are examined against various household background characteristics like household per capita consumption, rural and urban setup, region and district. Results are compared with latest [16] report available to have comparative discussions.

Of the total households interviewed $(n=1827)$ across the districts, about $43 \%(n=779)$ of the households were engaged in some type of micro-enterprises; ran one or more farm or non-farm micro-enterprises. Table VI presents details of the types of micro-enterprises the households had run at least for 2 years preceding the survey, and the average monthly business incomes and expenditures on food items. According to [13] report, approximately $21 \%$ of households had run nonfarm enterprises which was highly presumed to provide profit-based income and off-farm employment to a significant proportion of households in the country. Similar proportions of households are found to have run micro-enterprises: $22.5 \%$ non-farm micro-enterprises and $77.5 \%$ farm microenterprises.

The results indicate that households who were engaged in farm micro-enterprises, over $61 \%$ were involved in selling Grains/cereals, followed by horticulture (selling vegetables and over half and other crops such as rice and beans. According to [13], over $56 \%$ of all non-agricultural enterprises were engaged in wholesale, retail trade and restaurants and manufacturing enterprises forms one third of all non-agricultural enterprises (33.3\%).

\begin{tabular}{lcc}
\multicolumn{3}{c}{ TABLE VI: DISTRIBUTION OF MICRO-ENTERPRISE DIVERSITY } \\
\hline Types of micro-enterprises (n=779) & Percentage & Malawi \\
\hline 13$]$ \\
\hline Farm micro-enterprises (n=604) & 75.7 & 78.9 \\
Cereals & 61.8 & 77.1 \\
Horticulture & 16.2 & 31.0 \\
Legumes and Pulses & 18.4 & 26.8 \\
Tubers and Roots & 14.3 & 15.7 \\
Other crops & 59.4 & 62.2 \\
Non-Farm micro-enterprises (n=175) & & \\
Whole sales & 22.4 & 21.1 \\
Retail sales & 10.3 & 12.1 \\
Restaurant/bar & 34.9 & 40.3 \\
Manufacturing & 29.7 & 32.1 \\
Transport/Storage & 27.1 & 33.3 \\
Community/Social Services & 6.8 & 4.5 \\
Others (construction, mining, real & 3.5 & 4.7 \\
estates, financing, etc.) & 12.2 & 8.1 \\
\hline
\end{tabular}

Note that percentages for each type of micro-enterprise add to more than 100 percent since households run more than one enterprise. Categorization of enterprises based on NSO's 2013 survey report/

One of the objectives of this study was to assess the contribution of enterprises on household dietary diversifications (i.e., proxy access to food items) through total household income realized from running small businesses, and mostly spent on household food items. As reported in Table VII, households that are engaged in farm microbusinesses, on average, they spent 51.15 of their income on 
household food items; implying that these businesses are helping the households to supplement the shortage of foods in the households, though it is difficult to save and reinvest to revamp the businesses to higher level due to diversions to high expenditure on food items.

TABLE VII: HoUSEHOLD INCOME, EXPENDITURES, AND PERCEPTIONS OF ADEQUACY OF FOOD

\begin{tabular}{|c|c|}
\hline Farm micro-enterprises $(\mathrm{n}=604)$ & \\
\hline Characteristics & Means or Percentages \\
\hline Monthly mean income (MK) & $6601.18 \pm 7012.80$ \\
\hline Monthly mean food expenditure (MK) & $3373.53 \pm 2288.30$ \\
\hline Proportion spent on food items $(\%)$ & 51.1 \\
\hline \multicolumn{2}{|l|}{ Number of meals per day $(\%)$} \\
\hline 1 & 5.4 \\
\hline 2 & 75.1 \\
\hline 3 & 19.6 \\
\hline \multicolumn{2}{|l|}{ Perceptions adequate food for household (\%) } \\
\hline Adequate & 17.0 \\
\hline Inadequate & 80.1 \\
\hline Over-adequate & 2.9 \\
\hline Perceptions adequate food for children & 12.7 \\
\hline \multicolumn{2}{|l|}{ Non-farm micro-enterprises $(\mathrm{n}=175)$} \\
\hline Characteristics & Means or Percentages \\
\hline Monthly mean income (MK) & $6444.08 \pm 7080.88$ \\
\hline Monthly mean food expenditure (MK) & $3763.42 \pm 2357.18$ \\
\hline Proportion spent on food items $(\%)$ & 58.4 \\
\hline \multicolumn{2}{|l|}{ Number of meals per day $(\%)$} \\
\hline 1 & 6.1 \\
\hline 2 & 77.1 \\
\hline 3 & 16.8 \\
\hline \multicolumn{2}{|l|}{ Perceptions adequate food for household } \\
\hline Adequate & 25.0 \\
\hline Inadequate & 76.2 \\
\hline Over-adequate & 1.2 \\
\hline Perceptions adequate food for children & 16.1 \\
\hline
\end{tabular}

It is imperative to understand the patterns of income and profits, as well as expenditures from such small businesses so that the welfare of the household could be understood for policy makers in order to assist such households in enhancing their livelihoods through reduction of food and nutrition insecurities, in general; be it through improving access to loans, cash transfer, agricultural subsidy or related policies. One specific policy could be via availability of funds to make rural households self-sufficient through privatization and linking markets to both farm and non-farm micro-enterprises.

In term of monthly food expenditure and average budget allocation, regardless of the type of micro-enterprises the households were involved, there is no significant different $(\rho>0.05)$ in monthly expenditure breakdown and average budget shares devoted to food and non-food items for the households. The high allocation of (51.1 to $58.4 \%$ farm and non-farm micro-enterprises, respectively) to food expenditure also suggests that the households having difficulties to get out of the vicious cycle of poverty as a whole.

In fact, when the household heads were asked on the adequacy of food for the household, with no significant difference $(\rho=0.2628>0.05)$, most household heads ( 80.15 for farm micro-enterprises and $76.2 \%$ from non-farm microenterprises) had believed that there was inadequate food for the households; while about $16 \%$ also think that there is no adequate food for children in the households.

According to [13] report, $49 \%$ of the country's population experienced food shortage in the 12 months previous to its IHS3 survey. In rural areas, lack of farm inputs and weather conditions represent almost $70 \%$ of the causes for food shortage; while among urban population, 30\% experienced food shortage, and the main cause identified was the limited economic access to food as a result of excessive food prices in the market. Given these experiences, it is not surprising to record high perceptions of households complaining about inadequate food for the households in this survey.

\section{E. Household Dietary and Micro-enterprises Diversifications}

In subsistence rural economy like Malawi, farm and nonfarm business diversifications is crucial to improve the livelihoods of the household, especially implementing various agricultural policies, especially jointly food and nutrition policies, as well as reduction of rampant poverty in the country.

Table VIII reports descriptive statistics on the main household and institutional characteristics, as well as household dietary, micro-enterprises and farm production diversifications. As demonstrated previously, since there are no generally significant differences among the household characteristics. Table VIII also reports household characteristics for the entire household involved in microenterprising.

The mean dietary diversity at the household level is about 5 ; it means the average household has consumed five food groups during the reference day or recall period. The mean farm production diversity is also coincidentally about 5; implying that the household has produced, on average, five groups of agricultural products. Similarly, the microenterprise diversity results indicate the household has run, on average, 3 types of micro- businesses for at least two years preceding the survey.

TABLE VIII: HOUSEHOLD, INSTITUTIONAL AND FARM SAMPLE

\begin{tabular}{|c|c|c|}
\hline \multicolumn{3}{|c|}{ CHARACTERISTICS } \\
\hline Variable (measurements) & Description & Estimates \\
\hline $\begin{array}{c}\text { Household dietary } \\
\text { diversity (mean, SD and } \\
\text { median) }\end{array}$ & $\begin{array}{c}\text { Number of food groups } \\
\text { consumed by the households } \\
(1-12 \text { groups })\end{array}$ & $4.9,2.1,5$ \\
\hline $\begin{array}{c}\text { Farm production } \\
\text { diversity (mean, SD and } \\
\text { median) }\end{array}$ & $\begin{array}{l}\text { Number of farm product } \\
\text { groups cultivated by the } \\
\text { households (1-10 groups) }\end{array}$ & $4.95,2.1,5$ \\
\hline $\begin{array}{c}\text { Micro-enterprises } \\
\text { diversity, (mean, SD and } \\
\text { median) }\end{array}$ & $\begin{array}{c}\text { Number of small farm and } \\
\text { non-farm business groups ran } \\
\text { by the households ( } 1-12 \\
\text { groups) }\end{array}$ & $3.01,1.2,3$ \\
\hline $\begin{array}{l}\text { Age (mean years, SE, } \\
\text { SD, median) }\end{array}$ & Household head (years) & $\begin{array}{l}43.1,0.34 \\
9.4,42\end{array}$ \\
\hline $\begin{array}{l}\text { Education (mean years, } \\
\text { SE, SD, median) }\end{array}$ & $\begin{array}{l}\text { Household head, year of } \\
\text { schooling, 1-16 years }\end{array}$ & $\begin{array}{c}4.9,0.09,2.6 \\
5\end{array}$ \\
\hline $\begin{array}{l}\text { Occupation (mean years, } \\
\text { SD, median) }\end{array}$ & Household head, 1-5 groups & $1,0.8,1$ \\
\hline Household size & Number of persons (number) & 4.9 \\
\hline Household head & Sex $($ male $=1)$, percentage & 71.8 \\
\hline $\begin{array}{l}\text { Household land } \\
\text { ownership }\end{array}$ & $\begin{array}{l}\text { Land ownership (own=1), } \\
\text { percentage }\end{array}$ & 69.1 \\
\hline Marital status & $\begin{array}{l}\text { Household head }(1=\text { married }), \\
\text { percentage }\end{array}$ & 74.3 \\
\hline Land (mean, SE, SD) & $\begin{array}{l}\text { Land size owned by } \\
\text { households (hectare) }\end{array}$ & $\begin{array}{l}0.66,0.01 \\
\quad 0.45\end{array}$ \\
\hline Credit or loan & $\begin{array}{l}\text { Access to credit/loan } \\
\text { (yes }=1) \text {, percentage }\end{array}$ & 33.3 \\
\hline $\begin{array}{l}\text { Sources of loan (mean, } \\
\text { SD and median) }\end{array}$ & $\begin{array}{l}\text { Number of sources of } \\
\text { loans/credits, } 1-7 \text { groups }\end{array}$ & $6,2.6,5$ \\
\hline $\begin{array}{l}\text { Health/Nutrition } \\
\text { information }\end{array}$ & $\begin{array}{l}\text { At least a household member } \\
\text { received health information } \\
\quad(\text { yes }=1), \text { percentage }\end{array}$ & 27.5 \\
\hline Expenditure (MK) & Household Food expenditure & 3568.75 \\
\hline Total income (MK) & $\begin{array}{l}\text { Amount income from micro- } \\
\text { businesses }\end{array}$ & 6522.62 \\
\hline
\end{tabular}




\section{F. Empirical Econometric Models and Strategies on Diversifications}

In order to investigate the relationship between various socio-economic and institutional variables including nutrition education, micro-enterprises diversification, household food dietary diversification, as well as household dietary diversity, the following regression models were applied separately:

\section{G. Micro-enterprise Diversity}

To investigate the effects of various socio-economic and institutional characteristics on farm and non-farm microenterprises, and Table IX presents estimations from the Negative Binomial model.

TABLE IX: NEGATIVE BINOMIAL REGRESSION ANALYSIS OF SOCIOECONOMIC AND INSTITUTIONAL CHARACTERISTICS ON HOUSEHOLD MICRO-ENTERPRISES DIVERSITY

\begin{tabular}{ccccccc}
\multicolumn{9}{c}{ MICRO-ENTERPRISES DIVERSITY } \\
\hline farmbusino t & IRR & $\begin{array}{c}\text { Std. } \\
\text { Err. }\end{array}$ & $\mathrm{Z}$ & $\mathrm{P}>\mathrm{Z}$ & \multicolumn{2}{c}{$\begin{array}{c}\text { [95\% Conf. } \\
\text { Interval] }\end{array}$} \\
\hline hhsex & 0.386 & 0.243 & -1.51 & 0.131 & 0.110 & 1.328 \\
hhage & 1.004 & 0.018 & 0.23 & 0.812 & 0.968 & 1.040 \\
hhsize & 2.376 & 0.634 & 3.24 & 0.001 & 0.968 & 4.008 \\
hhoccup & 0.986 & 0.127 & -0.11 & 0.916 & 0.766 & 1.270 \\
hhedu & 0.607 & 0.068 & -4.45 & 0.000 & 0.487 & 0.756 \\
maristatus & 4.448 & 1.160 & 5.72 & 0.000 & 2.668 & 7.417 \\
accesscredit & 0.389 & 0.168 & -2.18 & 0.029 & 0.166 & 0.908 \\
constraints & -2.823 & 0.675 & 4.34 & 0.000 & 1.767 & 4.509 \\
agrobusiown & 0.785 & 0.114 & -1.67 & 0.095 & 0.591 & 1.043 \\
lnalpha $(\alpha)$ & -2.497 & & 0.443 & -3.365 & & -1.629 \\
alpha & 0.0823 & \multicolumn{7}{c}{0.0365} & 0.0346 & & 0.196
\end{tabular}

Likelihood-ratio test of alpha $=0$ : chibar2 $(01)=110.37$

Prob $>=$ chibar $2=0.000$

\begin{tabular}{|c|c|}
\hline & LR chi $2=22.89$ \\
\hline Dispersion mean $=3$ & Prob $>$ chi $2=0.0065$ \\
\hline Log likelihood $=-65.403402$ & Pseudo R2 $=0.1489$ \\
\hline
\end{tabular}

For farm and non-farm micro-enterprise diversity, the goodness-of-fit chi-squared test $\left(n=767, \chi^{2}=22.89, \rho=0.0065\right.$ $<0.05)$ is statistically significant and the negative binomial regression fits the data well. Furthermore, estimate of overdispersion parameter of $0.0823\left(\mathrm{H}_{0}: \alpha=0, \rho=0.000<0.001\right.$, reject $\mathrm{H}_{0}$ ) indicating that the data do not fit the Poisson model; but, the negative binomial regression [18] and [19], which is suitable for over-dispersed data is used for estimating microenterprise diversity model as reported in Table XV. The Incident Rate Ratios (IRRs), $\rho$-values for each independent variable and their $95 \%$ confidence intervals were computed for the model. The IRRs are interpreted as percent change in the expected count, thus by what percentage the microenterprise diversity score change when the explanatory variable changes by one unit.

Note that the mean micro-enterprise diversity is 3 ; indicating that household has run 3 businesses, on average, for two years preceding the survey. As reported in Table IX, the negative binomial regression estimates suggest that household size, household head education, marital status, access to credit and agribusiness ownership positively and significantly $(\rho=0.000<0.05)$ affect household microenterprise diversity.

The IRRs parameter estimates (Table IX): household head education, access to credit and agro-business ownership increased household micro-enterprises diversity by $60.7 \%$, $38.9 \%$, and $78.5 \%$, respectively, holding other things constant. However, if household size were to increase by one person (productive age), the rate ratio would be expected to have 2.37 times greater effect for micro-enterprise diversity; similarly, for married couples compared to singles or divorced, other things being kept constant, are expected to have a rate 4.45 times greater for micro-enterprise diversity. The highest impact comes from ownership of the business confirming that as $90.5 \%$ of the owners are the household head themselves, which is also reflected as $92.5 \%$ in 2013 [13].

Household head sex, household head age and household occupation are also positively but not significantly associated with micro-business diversity; while constraints affect microenterprise diversity negatively, that is the constraints are expected to have 2.28 times reduction in running microenterprise diversity. It is important to note that business constraints such as lack of collaterals, defaults, delays in loan processing, etc. have the most negative effect on microbusiness activities, in which the government has to pay attention to easy such obstacles for poor household to encourage them in running their own farm and/or non-farm micro-enterprises.

\section{H. Household Dietary Diversity}

According to [20], although there is dramatic increase in maize yields since the implementation of the Farm Income Subsidy Program (FISP), which is the major national program that subsidizes fertilizer and improved seed primarily for maize cultivation, have likely enhanced household maize self-sufficiency, but not necessarily achieving nutrition security. Similarly, [21] reported that Malawian diets remain poorly diversified. Indeed, the contribution of foods other than maize to national per capita dietary energy supply appears to have actually decreased slightly in recent years. Poorly diversified diets characterized by an overreliance on starchy staples are a red flag for malnutrition. Conversely, diets which include a variety of foods are considered important for positive health. Diets which include nutrientrich legumes and animal-source foods as well as vitamin-rich fruits and vegetables are associated with micronutrient adequacy [21].

To determine the relationship between household dietary diversity (HHDD), which proxies food access to variety nutritious food groups, a modified Household Dietary Diversity Score was calculated for each household using recall data on consumption of foods over the previous 24 hours during the survey [14]. As suggested previously through various literatures such as a study in Zimbabwe [2], the shorter recall period was used in order to improve the accuracy of estimates compared with longer recall periods of a week or a month.

Following [14], 'Household dietary diversity score (HDDS) for measurement indicator guide', the household dietary diversity is a count variable that took values between 1 and 12 for the household food consumption data collected based on the recall period of 24 hours. The modified HHDD is household dietary diversity score is used as dependent variable, and Poisson regression model was used for estimations.

Table $\mathrm{X}$ presents Poisson regression results using various socio-economic, institutional characteristics, as well as farm 
production and micro-enterprise diversifications as independent variables.

TABLE X: POISSON REGRESSION ANALYSIS OF SOCIO-ECONOMIC, INSTITUTIONAL CHARACTERISTICS AND MICRO-ENTERPRISES DIVERSITY ON HOUSEHOLD FOOD DIETARY

\begin{tabular}{|c|c|c|c|c|c|c|}
\hline hhdietrysc $\sim \mathrm{e}$ & $\mathrm{IRR}^{1}$ & $\begin{array}{l}\text { Std. } \\
\text { Err. }\end{array}$ & $\mathrm{Z}$ & $\mathrm{P}>\mathrm{Z}$ & \multicolumn{2}{|c|}{$\begin{array}{l}\text { [95\% Conf. } \\
\text { Interval] }\end{array}$} \\
\hline hhage & 1.033 & 0.003 & 12.54 & 0.000 & 1.028 & 1.039 \\
\hline hhoccup & 1.442 & 0.0445 & 11.89 & 0.000 & 1.357 & 1.532 \\
\hline hhedu & 1.026 & 0.0149 & 1.78 & 0.075 & 0.997 & 1.056 \\
\hline maristatus & 1.958 & 0.119 & 10.97 & 0.000 & 1.736 & 2.208 \\
\hline expendfood & 0.999 & 0.001 & -1.95 & -1.95 & 0.999 & 1.000 \\
\hline landsize & 1.028 & 0.0790 & 0.36 & 0.718 & 0.883 & 1.197 \\
\hline farmprodiv $\sim \mathrm{t}$ & 1.33 & 0.0003 & 10.11 & 0.000 & 1.250 & 1.370 \\
\hline bothmicro & 0.997 & 0.0002 & -11.72 & 0.000 & 0.997 & 0.998 \\
\hline utilizatio m & 0.953 & 0.022 & -2.08 & 0.038 & 0.912 & 0.997 \\
\hline lnalpha $(\alpha)$ & -19.616 & & 307.594 & -622.489 & & 583.257 \\
\hline alpha & $3.03 \mathrm{e}-09$ & & $9.31 \mathrm{e}-07$ & $4.5 e-271$ & & $2.0 \mathrm{e}+253$ \\
\hline $\begin{array}{l}\text { Likelihood-ratio } \\
\text { Prob }>=\text { chibar } 2= \\
\text { LR chi } 2=955.96 \\
\text { Prob }>\text { chi } 2=0.0 \\
\text { Log likelihood }= \\
\text { Pseudo R2 }=0.92\end{array}$ & $\begin{array}{l}499 \\
\text { it of alpha= }\end{array}$ & : chibar2 & $01)=3.9 \mathrm{e}-06$ & & & \\
\hline
\end{tabular}

The goodness-of-fit chi-squared test $\left(\chi^{2}=955.96\right.$, $\rho=0.000<0.05)$ and LR estimates suggest that Poisson model fits reasonably well the household dietary diversity data. Unlike the two previous negative models fitted to microenterprise and farm production data, no over-dispersion is detected here as the over-dispersion parameter estimate $(\alpha=$ $0.000000003 \approx 0$ with $\rho=0.499>0.05$ ) suggests that the null hypothesis $\left(\mathrm{H}_{0}: \alpha=0\right)$ is not rejected, and thus the Poisson model is appropriate for the household dietary diversity data.

The Incident Rate Ratios (IRRs), $\rho$-values for each independent variable and their $95 \%$ confidence intervals were computed for the model. The IRRs are interpreted as percent change in the expected count, thus by what percentage the dietary diversity score change when the explanatory variable changes by one unit [27], [22] and [23].

Mean HDDS for surveyed households was 5 for the 12 groups (Table VIII), that is, the average farm household perhaps consumed 5 different types of food groups in the course of recall period preceding the survey. The IRRs values of household head age $(3.3 \%, \rho=0.000<0.001)$, household occupation $(44.2 \%, \rho=0.000<0.001)$, marital status of household head $(95.85 \%, \rho=0.000<0.001)$, expenditure on food items $(99.9 \%, \rho=0.000<0.001)$, land size $(2.8 \%$, $\rho=0.094<0.1)$, farm production diversity $(33 \%$, $\rho=0.000<0.001)$ and micro-enterprise diversity $(99.7 \%$, $\rho=0.000<0.001$ ) positively and significantly are associated to household dietary diversity; this is to say that factors have significantly impacted household dietary diversity or food access in quality and quality in the districts of Malawi.

Of all the factors associated with household nutritional outcomes, farm and non-farm enterprise diversity, farm production diversity, as well as expenditure on food items had played the major role in influencing nutritional status of the household including children. Increasing farm and non-farm micro-enterprise diversity by one business group is associated with the possibility of consuming all 12 groups of food by the household; as theory postulates, perhaps this is due to

\footnotetext{
${ }^{1}$ For IRRs estimates greater than 1 , the interpretation is different when the
} value is above or below value of 1 . Refer for more to Poisson additional monthly income from the businesses that mostly lead to high food expenditure in the households. Similarly, increasing farm production diversity (i.e., increasing farm production group by 1 out of 10) increases household dietary diversity by $33 \%$ (i.e., 4 food groups out of 12 could be consumed, given 5 food groups consumption on average). A study in Zimbabwe [2] reported that increasing crop diversity by one crop species is associated with only a 4 and $5 \%$ increase in the number of food groups consumed by the household and women, respectively.

Holding other things constant, it is also found that nutrition education $(34.2 \%, \rho=0.000<0.001)$ influenced household food dietary diversity more than household heads with formal education who achieved only standard 5 level, on average; suggesting that nutrition education, if directly delivered to the household heads regardless of their formal education level, is one of the major factors that can positively and significantly affect household dietary diversity or nutritional status of the household in the districts of Malawi [24], [25, and [26].

National Statistical Office [13] report also explains that participation in nutrition program decreases with increases, especially in mother's education; usually mothers who are educated are likely to be conversant with health issues, able to read health materials for the benefit of their families. It is highest among children of uneducated mothers (8.4\%) and lowest among children of mothers with a secondary education (7\%).

\section{CONCLUSION AND POLICY IMPLICATIONS}

This study had investigated the nexus between farm and non-farm micro-enterprises diversity and household dietary diversity of households in selected districts of Malawi. Unlike many studies done in developing countries, this study jointly and in details analyzed the roles of socio-economic and institutional characteristics, agro-based and non-agro-based enterprises. Information on nearly 75 variables from a sample

regression/STATA annotated output. Available: https://stats.idre.ucla.edu/stata/output/poisson-regression/ 
of 1827 respondents was collected from six districts with high concentrations of small businesses and populations and nearly 775 households with both farm $(n=604)$ and non-farm $(n=175)$ enterprises were identified from the total sample.

The usual descriptive statistics on the households' socioeconomic and institutional characteristics were done, and then Poisson and Negative binomial regressions were accordingly fitted to investigate the impacts of socioeconomic, institutional characteristics, as well microenterprise diversity and farm production diversity on household dietary diversity. In lieu of development activities and with renewed attention of nutritional status of households in developing countries; increasing farm and non-farm microenterprise diversity by one business group is associated with the possibility of consuming all 12 groups of food by the household.

Based on recently introduced nutritional programmes, and holding other things constant, it is surprisingly found that nutrition education $(34.2 \%, \rho=0.000<0.001)$ influenced household food dietary diversity more than household heads with formal education who achieved only to standard 5 level, on average; suggesting that nutrition education, if directly delivered to the household heads regardless of their formal education level, is one of the major factors that can positively and significantly affect household nutritional status including children.

These findings demonstrate the importance of household level analysis. Taken together, the results show the need to promote nutrition education, farm and non-farm microenterprises diversifications, as complementary and supplementary interventions for improving household dietary diversity. These results also resonate to the Government of Malawi's overarching policy goal of furthering diversify income-generating economic activities in order to become less reliant on the hand-outs and donors. Energy and food supply are essential if the country is aiming to expand its industry and service sector with healthy population [27] and [28].

Considering still agricultural and rural sector development as the most crucial for food security, nutrition security and pro-poor growth, the sector is currently undiversified at farm level. The development of agriculture and agribusiness intends to aid the diversification and value addition of the sector. Taking into consideration the availability of various agricultural and related policies - Agricultural Sector Wide Approach (ASWAp), Food and Nutrition Security Policy, Economic Recovery Plan (ERP), Scaling Up Nutrition (SUN), (2005) and a National Nutrition Policy and Strategic Plan (NNPSP), etc. The following policy implications and recommendations could be drawn from this research, as well.

\section{A. Policy Implications}

1) Create conducive environment (more access to credits, start-up capital, etc.) to economic competitiveness and economic empowerment of youth, women, farmers and micro, small and medium enterprises; avoid sporadic support to smallholder farmers and increase access to credit with meaningful amount as start-up capital and easing on some constraints such as need for collaterals and high interest rates.

2) Scale up and reorganize extension services targeting nutrition, agribusiness and cooperative programmes focusing on priority crops in their primary growing areas (maize, groundnuts, soya beans, sunflower, pigeon peas, horticulture, and dairy).

3) Work together with private sector to generate greater private investments in agricultural development and achieve sustainable food and nutrition security outcomes and poverty reduction; as well as improve access to land, water, and basic infrastructure to support food and nutrition security.

4) Resonate the importance of micro-enterprises diversity through major agricultural policies such as ASWAP and FISP since these policies focus on maize and leaves no room to support micro-enterprising related farm and non-farm products. There is a need to reconsider the FISP focus and approach to boost overall agricultural production and microenterprise diversities.

Furthermore, from literature reviews, it is observed that Malawi has very good food and nutrition policies, but most of them were not implemented due to various political and financial reasons, as well as suspension of donors' grants. Thus, improvement on transparency and accountability should be reinforced as there are crucial to development including nutritional status of the majority household in country. In addition, both qualitative and quantitative results suggest that reduction of poverty is crucial as poverty level is very high (recently UN reports that Malawi is the $3^{\text {rd }}$ poorest country in the World). Evidently and undeniably, the cause of all difficulties and ills in the country including nutrition insecurity is poverty. Reduce rampant poverty through social and economic activities, as well as, implementing pro-poor policies.

\section{ACKNOWLEDGMENT}

We would like to commend the African Economic Research Consortium (AERC, Nairobi) for financial support for this study, and special thank goes to Dr. Innocent Matshe and Dr.Mark Karori for their encouragements, moral support and Ms. Evar Kiambuthi and Ms. Bertha Chedeye for facilitating all related activities. Highly appreciate feedback and comments from LUANAR and UNIMA colleagues.

\section{REFERENCES}

[1] H. Malapit, S. Kadiyala, A. R. Quisumbing, K. Cunningham \&P Tyagi. Women's empowerment mitigates the negative effects of low production diversity on maternal and child nutrition in Nepal. The Journal of Development Studies. CC-BY-NC-ND-4.0, pp 1097-1123. Sept. 2015. Available: https://doi.org/10.1080/00220388.2015.1018904.

[2] C. Murendo, B. Nhau, K. Mazvimavi, T. Khanye, and G. Gwara. "Nutrition education, farm production diversity, and commercialization on household and individual dietary diversity in Zimbabwe." Food and Nutrition Research. Vol. 62, pp 1276-87, May 2017.

[3] K. Hirvonen, J. Hoddinott, B. Minten, and D. Stifel, “Children's diets, nutrition knowledge, and access to markets." World Development. Vol. 95, pp 303-15, April 2017.

[4] C. Carletto and A. Guelfi. "Agricultural commercialization and nutrition revisited: empirical evidence from three African countries." Food Policy. 67, pp 106-18. February 2017.

[5] A. Diange. A. (2003). 'Impact of Access to Credit on Maize and Tobacco Productivity in Malawi', in Integrated Micro-Credits, MicroEnterprises and Market Reforms in Subsistence Economy. A.K. Edriss, Ed. Las Vegas: International Publishers and Printers, 2003, chap 3, pp $35-60$. 
[6] M. Zeller, G. Schrieder, J. von Braun, and F. Heidhues. "Rural Finance for Food Security for the Poor (Implications for Research and Policy).' Food Policy Review 4. International Food Policy Research Institute, Washington, D. C. Vol. 3, pp 329-349, 1997.

[7] M. Zeller, E. MxNulty, and T. Nielsen. "Smallholder farmers' willingness to invest in irrigation schemes in Dedza, Malawi." American Journal of Rural Development. Vol. 4, No 2, pp 43-48, 2016.

[8] World Bank. Malawi- Public expenditure. Review, Country Office. November 2013.

[9] M. T. Ruel and H. Alderman. "Nutrition-sensitive interventions and programmes: how can they help to accelerate progress in improving maternal and child nutrition?" Lancet. Vol. 382, pp536-51, 2013.

[10] World Food Programme. (2016). Situation Report Malawi. Lilongwe. Rome, Italy.

[11] Food and Agricultural Organization. Review of food and agricultura policies in Malawi: Country Report 2014. Monitoring and Analyzing Food and Agricultural Policies (MAFAP). MAFAP Country Report Series, Rome. 2015.

[12] L. Aberman and T. Roopnaraine. Understanding household preferences on the production, consumption, and sale of nutritious crops, in Agriculture, food security, and nutrition in Malawi: Leveraging the links. N. L. Aberman, A. Meerman, and T. Benson, T. Eds. International Food Policy Research Institute, Washington, D. C.

[13] National Statistical Office. Malawi Demographic and Health Survey 2013. Zomba, Malawi. June 2014.

[14] A. Swindale and P. Bilinsky. Household dietary diversity score (HDDS) for measurement of household food access: Indicator guide. Vol. 2. Food and nutrition technical assistance project. FHI360/FANTA: Washington, DC. 2006.

[15] A. K. Edriss. Pearls of Applied Statistics. Lilongwe and Toronto: $i$ publishers, Canada. 2013

[16] National Statistical Office. Statistical Yearbook 2010. Zomba, Malawi. 2011c.

[17] E. L. Piza. "Using Poisson and Negative Binomial regression models" Available:

https://pdfs.semanticscholar.org/087c/ea2406c9ea6e26d2c8c1b77617 da75b0e9c9.pdf/.

[18] J. M. Hilbe. Negative binomial regression. $2^{\text {nd }}$ ed. Cambridge: Cambridge University Press, UK. 2011

[19] A. C. Cameron and P. K. Trivedi. Micro-econometrics using Stata. College Station, Texas: Stata Press, TX. 2010.

[20] C. Chibwana and M. Fisher. The Impacts of agricultural inputs subsidies in Malawi. Malawi Strategy Support Program Policy Note 5. IFPRI. Washington DC. 2011.

[21] J. Mazunda, H. Kankwamba and K. Pauw. Food and nutrition Security implications of crop diversification in Malawi's farm households. IFPRI-Malawi Country Strategy Publications. 2015.

[22] C. Arndt, K. Pauw, and J. Thurlow. The Economy wide impacts and risks of Malawi's farm input subsidy Programme. Available: https://papers.ssrn.com/sol3/papers.cfm?abstract_id=2530886.

[23] F. Harris and A. Shresth. "Status and determinants of intra-household food allocation in rural Nepal." European Journal of Clinical Nutrition. Vol. 72, pp1524-1536, 2018.

[24] Government of Malawi, Ministry of Agriculture and Food Security. The Agriculture Sector Wide Approach ASWAp Malawi's prioritized and harmonized Agricultural Development Agenda. Policy paper. Lilongwe, Malawi. 2010.

[25] Ministry of Agriculture. Review of food and agricultural policies in Malawi Country Report 2014. Lilongwe, Malawi. Report 2015.

[26] A. S. Snapp and M. Fisher. "Filling the maize basket' supports crop diversity and quality of household diet in Malawi." Food Security, Vol. 7, pp 83-96, 2015.

[27] S. Maxwell and A. Fernando. "Cash crops in developing countries: the issues, the facts, the policies." World Development. Vol. 17, No. 11 pp1677-1708. 1989.

[28] R. Martorell., P. Melgar, J. A. Maluccio, A. D. Stein, and J. A. Rivera "The nutrition intervention improved adult human capital and economic productivity." Journal of Nutrition. Vo. 140, No. 2. Pp 4114, February 2, 2010.

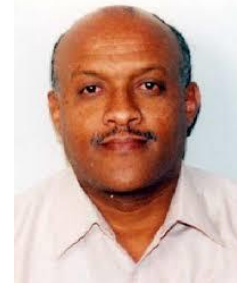

Professor Abdi-Khalil Edriss is full Professor of Applied Economics and Statistics at the Lilongwe University of Agriculture and Natural Resources, Department of Agricultural and Applied Economics. He has taught at many universities in SADC and COMESA regions, as well as in Canada. He holds dual BA.BSc in Mathematical Science and Economics, MSc in Statistics, MA Economics, and $\mathrm{PhD}$ in Economics, Canada. Among many awards and recognitions, recipient of Common Wealth Quality of Life Awards, University of Malawi outstanding researcher recognition and $\mathrm{ABI}$ international research medal. Supervising several $\mathrm{MSc}$ and $\mathrm{PhD}$ national and international students. His areas of interest are Applied Economics, Health Economics, Development Economics, Econometrics and MicroEconometrics. He has published over 80 research articles and 17 books in various areas including food security, health economics, sustainable development, adoption of technology, demography, research methods, applied statistics and econometrics. He has consulted several government ministries, UN organizations, the World Bank, Clinton Foundation, World Vision, Plan International, and among several projects, he is involved with African Economic Research Consortium (AERC), GIZ and RUFORUM research projects.

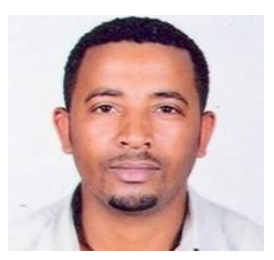

Dr. Abule Mehare is Assistant Professor at Haramaya University, School of Agricultural and Agribusiness. Dr. Mehare obtained his BSc in Agricultural Economics from Haramaya University (Ethiopia), MSc in Agricultural and Applied Economics under AERC Collaborative Agricultural and Applied Economics program (University of Malawi and University of Pretoria, South Africa), as well as his PhD in Agricultural and Resources Economics from Lilongwe University of Agriculture and Natural Resources (LUANAR, Malawi). His areas of interest are Applied Economics, Resources Economics, Econometrics, Development, and International Economics. He has published a number of papers and involved with projects funded by African Economic Research Consortium (AERC) 